\title{
No evidence for WU polyomavirus infection in chronic obstructive pulmonary disease
}

\author{
Felix C Ringshausen*1,2, Marei Heckmann ${ }^{1}$, Benedikt Weissbrich ${ }^{3}$, \\ Florian Neske ${ }^{3}$, Irmgard Borg ${ }^{1}$, Umut Knoop ${ }^{1}$, Juliane Kronsbein ${ }^{1}$, \\ Barbara M Hauptmeier ${ }^{1}$, Gerhard Schultze-Werninghaus ${ }^{1}$ and Gernot Rohde ${ }^{1}$
}

Address: ${ }^{1}$ Clinical Research Group "Significance of viral infections in chronic respiratory diseases of children and adults", University Hospital Bergmannsheil, Department of Internal Medicine III, Pneumology, Allergology and Sleep Medicine, Ruhr-University Bochum, Germany,

${ }^{2}$ Department of Medicine, Spital Bülach, Bülach, Switzerland and ${ }^{3}$ Institute of Virology and Immunobiology, University of Würzburg, Germany

Email: Felix C Ringshausen* - felix.ringshausen@web.de; Marei Heckmann - mareiheckmann@yahoo.com;

Benedikt Weissbrich - weissbrich@vim.uni-wuerzburg.de; Florian Neske - florian.neske@gmx.de; Irmgard Borg - irmgard.borg@rub.de;

Umut Knoop - umut.knoop@rub.de; Juliane Kronsbein - juliane.kronsbein@rub.de;

Barbara M Hauptmeier - barbara.hauptmeier@bergmannsheil.de; Gerhard Schultze-Werninghaus - gerhard.schultze-

werninghaus@bergmannsheil.de; Gernot Rohde - gernot.rohde@rub.de

* Corresponding author

Published: 28 August 2009

Infectious Agents and Cancer 2009, 4:12 doi:10.1186/1750-9378-4-12
Received: 13 November 2008

Accepted: 28 August 2009

This article is available from: http://www.infectagentscancer.com/content/4/I/12

(C) 2009 Ringshausen et al; licensee BioMed Central Ltd.

This is an Open Access article distributed under the terms of the Creative Commons Attribution License (http://creativecommons.org/licenses/by/2.0), which permits unrestricted use, distribution, and reproduction in any medium, provided the original work is properly cited.

\begin{abstract}
Human polyomaviruses are known to cause persistent or latent infections, which are reactivated under immunosuppression. Polyomaviruses have been found to immortalize cell lines and to possess oncogenic properties. Moreover, the recently discovered Merkel cell polyomavirus shows a strong association with human Merkel cell carcinomas. Another novel human polyomavirus, WU polyomavirus (WUPyV), has been identified in respiratory specimens from patients with acute respiratory tract infections (ARTI). WUPyV has been proposed to be a pathogen in ARTI in early life and immunocompromised individuals, but so far its role as a causative agent of respiratory disease remains controversial.
\end{abstract}

The objective of our study was to determine the prevalence of WUPyV infections in adult hospitalized patients with acute exacerbation of chronic obstructive pulmonary disease (COPD) and to establish its potential clinical relevance by comparison to patients with stable COPD hospitalized for other reasons than acute exacerbation of COPD (AE-COPD).

A total of 378 respiratory specimens, each 189 induced sputum and nasal lavage samples from 189 patients, who had been recruited in a prospective 2:I ratio case-control set-up between 1999 and 2003, were evaluated for the presence of WUPyV DNA by real-time PCR.

In the present study we could not detect WUPyV DNA in 378 respiratory specimens from 189 adult hospitalized patients with AE-COPD and stable COPD in four consecutive years.

Persistence of viral replication or reactivation of latent WUPyV infection did not occur. WUPyV may not play a major role in adult immunocompetent patients with AE-COPD and stable COPD. 


\section{Findings}

Polyomaviruses are small, non-enveloped viruses with a circular double-stranded DNA genome of approximately 5,000 base pairs. They are known to be capable of immortalizing animal and human cell lines. Their oncogenic potential has been demonstrated in vitro and in various animal cancer models and is accomplished by the integration of viral DNA into the host cell genome. Expression of the viral T-antigen is mandatory for cell transformation [1]. In the last years there has been a re-emergence of interest in human polyomaviruses as possible carcinogens as three novel polyomaviruses have been described in humans. While KI and WU polyomavirus have initially been detected in respiratory specimens [2,3], the Merkel cell polyomavirus (MCPyV) was observed to be clonally integrated into Merkel cell carcinomas (MCC), a rare but aggressive human skin cancer of neuroendocrine origin [4]. Meanwhile, MCPyV has also been described in respiratory specimens $[5,6]$, small cell lung cancer tissue [7], and there is increasing evidence for a strong association between MCPyV and MCC [8-12]. Recently a first study reported the detection of KIPyV DNA in lung cancer specimens [13], and many more studies targeting different human polyomaviruses, cancer entities and populations may be anticipated in the near future. However, the detection in the respiratory tract is not a unique feature of KI-, MC- and WUPyV and transmission by the respiratory route has already been suggested for the first two human polyomaviruses, BK and JC virus [14-16]. In 2007, WU polyomavirus (WUPyV) was identified in respiratory specimens from patients with acute respiratory tract infections (ARTI) [2]. It has been proposed to be a relevant pathogen in ARTI in early life and immunocompromised individuals, but so far its role as a causative agent of respiratory disease remains controversial as it was also found in healthy asymptomatic individuals $[17,18]$. WUPyV infections appear endemic worldwide [2], detection frequencies vary from $0.4 \%$ [19] to $7 \%$ [20] and coinfections with other respiratory viruses are common [21].

The aim of the present study was to determine the prevalence of WUPyV infections in adult hospitalized patients with acute exacerbation of chronic obstructive pulmonary disease (COPD) and to establish its potential clinical relevance by comparison to patients with stable COPD hospitalized for other reasons than acute exacerbation of COPD (AE-COPD).

A total of 378 respiratory specimens, each 189 induced sputum and nasal lavage samples from 189 patients were retrospectively evaluated for the presence of WUPyV DNA. Subjects with AE-COPD and stable COPD had been recruited in a prospective case-control study in a $2: 1$ ratio between October 1999 and April 2003. Underlying criteria, definitions and procedures have been the same as described previously [22]. Notably, patients with thoracic malignancies were excluded from the study. The induced sputum and nasal lavage samples were neatly stored in aliquots at $-70^{\circ} \mathrm{C}$ until further processing. DNA was extracted from the samples using the QIAamp DNA Blood Mini Kit (Qiagen, Hilden, Germany) and stored at $-20^{\circ} \mathrm{C}$ for further testing. Although the amplifiability of the assayed sample DNA was recently demonstrated by the detection of another novel respiratory agent, the human bocavirus [23], the human $\beta$-globin gene was amplified as a cellular gene on a LightCycler PCR platform (LightCycler $^{\circledR}$ Control Kit DNA, Roche, Mannheim, Germany) in order to demonstrate the integrity and sufficient quality of DNA in the assayed specimens. Primers and probe for the WUPyV real-time PCR assay were selected from the highly conserved C-terminal region of the large T-antigen that has been used for a qualitative WUPyV PCR previously [24]. Blasting of primer and probe sequences against GenBank excluded significant homologies with other organisms. The real-time PCR was performed in a final volume of $25 \mu \mathrm{l}$ consisting of $5 \mu \mathrm{l}$ of extracted DNA, the primers WU2958s (CCTGTTAGTGATTTTCACCCATGTA) and WU2865a (TGTCAGCAAATTCAGTAAGGCCTATATAT) at a final concentration of $400 \mathrm{nM}$, the probe WU2925s-TM (6FAM-AAAGTTGTGTATTGGAAAGAACTGTTAGACA-

TAMRA) at a final concentration of $100 \mathrm{nM}$, and $1 \times$ Quantitect probe master mix (Qiagen, Hilden, Germany) as described previously [25]. The cycling conditions were 50 cycles with $30 \mathrm{~s}$ at $95^{\circ} \mathrm{C}$ and $60 \mathrm{~s}$ at $60^{\circ} \mathrm{C}$ after a preheating step of $15 \mathrm{~min}$ at $95^{\circ} \mathrm{C}$. A plasmid containing the PCR product obtained with the primers AG0048 and AG0049 [2] cloned into the vector pCR2.1-TOPO (Invitrogen, Karlsruhe, Germany) was used as positive control and for the standard curve. Strict laboratory procedures were implemented to prevent PCR contamination. One negative control was amplified for every five samples. Plasmid spiking experiments were conducted in order to exclude PCR inhibition by induced sputum and nasal lavage samples. Data analysis was performed using SPSS, version 11.5 (SPSS Inc., Chicago, Illinois). Categorical data were compared by Pearson's chi-squared or Fisher's exact test, where appropriate. Normal distribution in continuous variables was determined with the Kolmogorov-Smirnov test and differences were subsequently determined either with the student's t-test or the Mann-Whitney-U test. All p values were calculated two-sided with statistical significance set to $\mathrm{p}<0.05$. The study was approved by the ethics committee of the Ruhr University, Bochum, Germany. All study participants gave their written informed consent prior to study inclusion.

The standard curve was linear over the range from 1+E01 to at least $1+\mathrm{E} 08$ copies per reaction. Spiking experiments using various dilutions of plasmid DNA that were incubated with fresh lower respiratory tract patient samples 
showed no inhibition of PCR reactions. The lower limit of detection of the applied real-time PCR assay was determined to ten copies per reaction corresponding to 400 copies per $\mathrm{mL}$ of starting material. A total of 378 respiratory specimens, each 189 induced sputum and nasal lavage samples, from 189 adult hospitalized COPD patients were investigated for the presence of WUPyV DNA by quantitative real-time PCR. Of those, 123 patients (65.1\%) had an acute exacerbation of COPD (AE-COPD) and 66 (34.9\%) had stable COPD. The demographic and clinical characteristics of the study population with regard to the COPD status are shown in Table 1 . The two groups were comparable in terms of age, sex, body mass index, smoking behavior, pack years and medication. Spirometric data before discharge were available for 77 of 123 patients (62.6\%) with AE-COPD, had significantly improved after treatment for acute exacerbation and were comparable to the baseline airflow in the control group. Significant differences were apparent for increased airflow limitation on admission, higher C-reactive protein levels and leukocyte counts in the AE-COPD group (Table 1).
WUPyV DNA was not detected in any of the tested samples when using a sensitive real-time PCR assay.

Our findings are in agreement with two recent studies from China [26] and the UK [27], which failed to detect WUPyV DNA in immunocompetent adults. The initial investigation by Gaynor et al. found four adults with altered immune status or multiple comorbidities to be positive for WUPyV [2]. None of the mentioned studies explicitly included patients with AE-COPD or stable COPD. The present population consisted of predominantly elderly COPD patients with severely impaired lung function and concomitant low dose oral steroid medication. In a previous study performed on a comparable population we demonstrated that AE-COPD was significantly associated with the detection of common respiratory viruses, foremost human rhinovirus, influenza virus A and respiratory syncytial virus, and that induced sputum had a higher viral yield than upper respiratory tract specimens in patients with AE-COPD [22]. Though our plasmid spiking experiments showed that PCR reactions were not inhibited by the assayed specimens, the use of diluted

Table I: Demographic and clinical characteristics of the study population

\begin{tabular}{|c|c|c|c|c|c|c|c|}
\hline \multirow[t]{2}{*}{ Variables } & \multicolumn{2}{|c|}{ All } & \multicolumn{2}{|c|}{$A E-C O P D$} & \multicolumn{2}{|c|}{ Stable COPD } & \multirow[t]{2}{*}{$P$ value ${ }^{a}$} \\
\hline & $\mathbf{n}$ & $\%$ & $\mathbf{n}$ & $\%^{d}$ & $\mathbf{n}$ & $\%^{d}$ & \\
\hline \multirow[t]{2}{*}{ Patients } & 189 & 100 & 123 & 65.1 & 66 & 34.9 & \\
\hline & $n$ & $\%$ e & $n$ & $\%$ e & n & $\%$ e & \\
\hline Sex & & & & & & & 0.35 \\
\hline Female & 39 & 20.6 & 28 & 22.8 & 11 & 16.7 & \\
\hline Male & 150 & 79.4 & 95 & 77.2 & 55 & 83.3 & \\
\hline Smoking behavior & & & & & & & 0.34 \\
\hline Active smokers & 53 & 28.0 & 32 & 26.0 & 21 & 31.8 & \\
\hline Non-smoker & 26 & 13.8 & 20 & 16.3 & 6 & 9.1 & \\
\hline Ex-smoker & 110 & 58.2 & 71 & 57.7 & 39 & 59.1 & \\
\hline Oral steroid medication & & & & & & & 0.52 \\
\hline Yes & 127 & 67.2 & 85 & 69.1 & 42 & 63.6 & \\
\hline No & 62 & 32.8 & 38 & 30.9 & 24 & 36.4 & \\
\hline Inhaled corticosteroids & & & & & & & 0.63 \\
\hline Yes & 126 & 66.7 & 80 & 65.0 & 46 & 69.7 & \\
\hline \multirow[t]{2}{*}{ No } & 63 & 33.3 & 43 & 35.0 & 20 & 30.3 & \\
\hline & Mean & SD & Mean & SD & Mean & SD & \\
\hline Age (years) & 67 & 10 & 68 & 9 & 65 & 11 & 0.17 \\
\hline \multirow[t]{2}{*}{ Body mass index $\left(\mathrm{kg} / \mathrm{m}^{2}\right)$} & 26.9 & 5.1 & 26.8 & 5.0 & 27.2 & 5.2 & 0.60 \\
\hline & Median & Range & Median & Range & Median & Range & \\
\hline Pack years ${ }^{b}$ & 30 & $21-20$ & 30 & $21-20$ & 30 & $21-20$ & $0.7 \mathrm{I}$ \\
\hline $\mathrm{FEVI}_{\mathrm{ad}}(\mathrm{L})$ & 1.0 & $0.4-2.6$ & 1.0 & $0.4-2.2$ & 1.2 & $0.5-2.6$ & $<0.0001$ \\
\hline $\mathrm{FEVI}_{\mathrm{ad}}(\%$ predicted $)$ & 38.0 & $16.7-79.0$ & 36.7 & 16.7-79.0 & 42.9 & 19.4-77.3 & 0.003 \\
\hline $\mathrm{FEVI}_{\text {dis }}(\mathrm{L})$ & 1.2 & $0.5-2.9$ & 1.2 & $0.6-2.9$ & 1.2 & $0.5-2.6$ & 0.53 \\
\hline $\mathrm{FEVI}_{\text {dis }}(\%$ predicted $)$ & 43.6 & $18.5-78.9$ & 44.3 & $18.5-78.9$ & 42.9 & $19.4-77.3$ & 0.90 \\
\hline $\mathrm{CRP}(\mathrm{mg} / \mathrm{dL})$ & 0.8 & $0.0-39.8$ & 1.0 & $0.0-39.8$ & 0.6 & $0.0-12.9$ & 0.0002 \\
\hline Leukocytes/nL & 10.5 & $0.7-27.2$ & 10.9 & $0.7-27.2$ & 10.1 & $5.1-24.0$ & 0.016 \\
\hline Oral steroid dose $(\mathrm{mg})^{\mathrm{c}}$ & 7.5 & $0-150$ & 10 & $0-150$ & 5 & $0-150$ & 0.098 \\
\hline
\end{tabular}

Notes: a $\mathrm{P}$ values with statistical significance are printed bold. $\mathrm{b}$ Pack years in active and ex-smokers. c Oral steroid dose in prednisone equivalent before admission. dPercent in line. e Percent in column. Abbreviations: (AE-)COPD = (acute exacerbation of chronic obstructive pulmonary disease. $\mathrm{CRP}=\mathrm{C}$-reactive protein. $\mathrm{FEVI}_{\mathrm{ad}}=$ forced expiratory volume in one second on admission. $\mathrm{FEVI}_{\text {dis }}=$ baseline forced expiratory volume in one second for the control group and before discharge after recovery from exacerbation for the AE-COPD group. SD = standard deviation. 
plasmid DNA instead of virus titers as a positive control and for the generation of the standard curve is an inevitable limitation of the present study. Infectious WU polyomavirus has yet to be isolated and cell lines susceptible to infection still need to be identified [28]. However, in the present study we could not detect WUPyV DNA in 378 respiratory specimens from 189 adult hospitalized patients with AE-COPD and stable COPD in four consecutive years between 1999 and 2003, whereas recent reports found WUPyV circulating in German, predominantly pediatric populations within and beyond our study period $[24,25,29]$.

Our findings support the hypothesis that primary WUPyV infection is acquired in early life rather than adulthood and suggest that persistence of viral replication or reactivation of latent WUPyV infection is not a common phenomenon in the adult COPD population. Hence, WUPyV may not play a major role in adult immunocompetent patients with AE-COPD and stable COPD. A clear linkage between WUPyV and human disease still remains to be determined.

\section{Competing interests}

The authors declare that they have no competing interests.

\section{Authors' contributions}

FCR conceived and designed the study, performed the statistical analysis, interpreted the data, supervised the study and drafted the manuscript. MH conducted the PCR experiments and revised the manuscript critically for important intellectual content. BW contributed to the study design, helped to establish the PCR assay and revised the manuscript critically for important intellectual content. FN constructed the plasmid for a positive control, contributed to the establishment of the PCR assay and revised the manuscript critically for important intellectual content. IB was involved in the processing of the specimens, UK, JK and BMH recruited the patients and all revised the manuscript critically for important intellectual content. GSW contributed to the study design and supervised the study. GR contributed to the study design, analysis and interpretation of data, supervised the study and revised the manuscript critically for important intellectual content. All authors read and approved the final manuscript.

\section{Acknowledgements}

This work was supported by an unrestricted research grant (2007-pneumo574) provided to FCR by the scientific committee of the University Hospital Bergmannsheil, Bochum, Germany. The authors are grateful to B. Schaerling, A. Wagner and M. Ulbrich for their excellent technical assistance in our lab.

\section{References}

I. zur Hausen $\mathrm{H}$ : Novel human polyomaviruses re-emergence of a well known virus family as possible human carcinogens. Int J Cancer 2008, 123:247-250.

2. Gaynor AM, Nissen MD, Whiley DM, Mackay IM, Lambert SB, Wu G, Brennan DC, Storch GA, Sloots TP, Wang D: Identification of a novel polyomavirus from patients with acute respiratory tract infections. PLoS Pathog 2007, 3:e64.

3. Allander T, Andreasson K, Gupta S, Bjerkner A, Bogdanovic G, Persson MA, Dalianis T, Ramqvist T, Andersson B: Identification of a third human polyomavirus. J Virol 2007, 8I:4|30-4I36.

4. Feng $H$, Shuda M, Chang Y, Moore PS: Clonal integration of a polyomavirus in human Merkel cell carcinoma. Science 2008, 319:1096-II00.

5. Goh S, Lindau C, Tiveljung-Lindell A, Allander T: Merkel cell polyomavirus in respiratory tract secretions. Emerg Infect Dis 2009, | 5:489-49|.

6. Kantola K, Sadeghi M, Lahtinen A, Koskenvuo M, Aaltonen LM, Mottonen M, Rahiala J, Saarinen-Pihkala U, Riikonen P, Jartti T, Ruuskanen $\mathrm{O}$, Söderlund-Venermo M, Hedman K: Merkel cell polyomavirus DNA in tumor-free tonsillar tissues and upper respiratory tract samples: Implications for respiratory transmission and latency. J Clin Virol 2009, 45(4):292-5. Epub 2009 May 22.

7. Helmbold P, Lahtz C, Herpel E, Schnabel PA, Dammann RH: Frequent hypermethylation of RASSFIA tumour suppressor gene promoter and presence of Merkel cell polyomavirus in small cell lung cancer. Eur J Cancer 2009, 45( I 2):2207-I I. Epub 2009 May 25.

8. Kassem A, Schopflin A, Diaz C, Weyers W, Stickeler E, Werner M, Zur Hausen A: Frequent detection of Merkel cell polyomavirus in human Merkel cell carcinomas and identification of a unique deletion in the VPI gene. Cancer Res 2008, 68:5009-50I3.

9. Shuda M, Feng H, Kwun HJ, Rosen ST, Gjoerup O, Moore PS, Chang $Y$ : $T$ antigen mutations are a human tumor-specific signature for Merkel cell polyomavirus. Proc Natl Acad Sci USA 2008, 105:16272-16277.

10. Duncavage EJ, Zehnbauer BA, Pfeifer JD: Prevalence of Merkel cell polyomavirus in Merkel cell carcinoma. Mod Pathol 2009, 22:516-521.

II. Sastre-Garau X, Peter M, Avril MF, Laude H, Couturier J, Rozenberg F, Almeida A, Boitier F, Carlotti A, Couturaud B, Dupin N: Merkel cell carcinoma of the skin: pathological and molecular evidence for a causative role of MCV in oncogenesis. J Pathol 2009, 2 I 8:48-56.

12. Wetzels CT, Hoefnagel JG, Bakkers JM, Dijkman HB, Blokx WA Melchers WJ: Ultrastructural proof of polyomavirus in Merkel cell carcinoma tumour cells and its absence in small cell carcinoma of the lung. PLoS One 2009, 4:e4958.

13. Babakir-Mina M, Ciccozzi M, Campitelli L, Aquaro S, Lo Coco A, Perno CF, Ciotti M: Identification of the novel KI Polyomavirus in paranasal and lung tissues. J Med Virol 2009, 8I:558-56I.

14. Goudsmit J, Wertheim-van Dillen P, van Strien A, Noordaa J van der: The role of BK virus in acute respiratory tract disease and the presence of BKV DNA in tonsils. J Med Virol 1982, 10:91-99.

15. Sundsfjord A, Spein AR, Lucht E, Flaegstad T, Seternes OM, Traavik $T$ : Detection of BK virus DNA in nasopharyngeal aspirates from children with respiratory infections but not in saliva from immunodeficient and immunocompetent adult patients. J Clin Microbiol I994, 32:1390-1394.

16. Monaco MC, Jensen PN, Hou J, Durham LC, Major EO: Detection of JC virus DNA in human tonsil tissue: evidence for site of initial viral infection. J Virol 1998, 72:9918-9923.

17. Abed $Y$, Wang D, Boivin G: WU polyomavirus in children, Canada. Emerg Infect Dis 2007, 13:1939-1941.

18. Norja P, Ubillos I, Templeton K, Simmonds P: No evidence for an association between infections with $\mathrm{WU}$ and $\mathrm{KI}$ polyomaviruses and respiratory disease. J Clin Virol 2007, 40:307-3II.

19. Lin F, Zheng M, Li H, Zheng C, Li X, Rao G, Wu F, Zeng A: WU polyomavirus in children with acute lower respiratory tract infections, China. J Clin Virol 2008, 42:94-102.

20. Han TH, Chung JY, Koo JW, Kim SW, Hwang ES: WU polyomavirus in children with acute lower respiratory tract infections, South Korea. Emerg Infect Dis 2007, I 3:1766-1768.

21. Le BM, Demertzis LM, Wu G, Tibbets RJ, Buller R, Arens MQ, Gaynor AM, Storch GA, Wang D: Clinical and epidemiologic character- 
ization of WU polyomavirus infection, St. Louis, Missouri. Emerg Infect Dis 2007, 13:1936-1938.

22. Rohde G, Wiethege A, Borg I, Kauth M, Bauer TT, Gillissen A, Bufe $A$, Schultze-Werninghaus G: Respiratory viruses in exacerbations of chronic obstructive pulmonary disease requiring hospitalisation: a case-control study. Thorax 2003, 58:37-42.

23. Ringshausen FC, Tan AY, Allander T, Borg I, Arinir U, Kronsbein J, Hauptmeier BM, Schultze-Werninghaus G, Rohde G: Frequency and clinical relevance of human bocavirus infection in acute exacerbations of chronic obstructive pulmonary disease. Int J Chron Obstruct Pulmon Dis 2009, 4: III-I I7.

24. Neske F, Blessing K, Ullrich F, Prottel A, Wolfgang Kreth H, Weissbrich B: WU polyomavirus infection in children, Germany. Emerg Infect Dis 2008, 14:680-68I.

25. Neske F, Blessing K, Prottel A, Ullrich F, Kreth HW, Weissbrich B: Detection of WU polyomavirus DNA by real-time PCR in nasopharyngeal aspirates, serum, and stool samples. J Clin Virol 2009, 44: II5-II8.

26. Ren L, Gonzalez R, Xie Z, Zhang J, Liu C, Li J, Li Y, Wang Z, Kong X, Yao Y, Hu Y, Qian S, Geng R, Yang Y, Vernet G, Paranhos-Baccalà G, Jin $\mathrm{Q}$, Shen $\mathrm{K}$, Wang J: WU and $\mathbf{K I}$ polyomavirus present in the respiratory tract of children, but not in immunocompetent adults. J Clin Virol 2008, 43(3):330-3. Epub 2008 Sep I4.

27. Abedi Kiasari B, Vallely PJ, Corless CE, Al-Hammadi M, Klapper PE: Age-related pattern of $K I$ and $W U$ polyomavirus infection. J Clin Virol 2008, 43: I23-125.

28. Dalianis T, Ramqvist T, Andreasson K, Kean JM, Garcea RL: KI, WU and Merkel cell polyomaviruses: a new era for human polyomavirus research. Semin Cancer Biol 2009, 19:270-275.

29. Kleines M, Scheithauer S, Hengst M, Honnef D, Ritter K, Muhler E, Hausler M: Low to medium WU-virus titers in young children with lower respiratory tract infections. Intervirology 2008, 5 I:444-446.

Publish with Bio Med Central and every scientist can read your work free of charge

"BioMed Central will be the most significant development for disseminating the results of biomedical research in our lifetime. "

Sir Paul Nurse, Cancer Research UK

Your research papers will be:

- available free of charge to the entire biomedical community

- peer reviewed and published immediately upon acceptance

- cited in PubMed and archived on PubMed Central

- yours - you keep the copyright

Submit your manuscript here:

http://www.biomedcentral.com/info/publishing_adv.asp
BioMedcentral 